\title{
Prediction of bovine ovulation by a rapid radioimmunoassay for plasma $\mathbf{L H}$
}

\author{
C. Bernard*†, J. P. Valet*, R. Béland*† and R. D. Lambert*†
}

*Laboratoire de Génétique moléculaire et humaine, Section reproduction, Local S-5, C.H.U.L., and $\dagger$ Département d'obstétrique-gynécologie, Faculté de médecine, Université Laval, 2705, boul. Laurier, Sainte-Foy, Québec, Canada G1V 4 G2

\begin{abstract}
Summary. A commonly used and specific plasma LH radioimmunoassay was modified to provide reliable results for cow $\mathrm{LH}$ concentrations in blood within 4-5 h. Blood samples were collected at 2- or $4-\mathrm{h}$ intervals from at least $24 \mathrm{~h}$ before the expected oestrus until after its onset. Thereafter, samples were collected at intervals of 2 or 4 days until the next oestrus. For the assay, the antigen-antibody reaction took place during a 2-h incubation at $37^{\circ} \mathrm{C}$. The immune complex was precipitated by addition of rabbit anti- $\gamma$-globulin and polyethylene glycol followed by an incubation at $22^{\circ} \mathrm{C}$ for $30 \mathrm{~min}$. The coefficient of variation between this assay and the standard assay was $<15 \%$. From a study of 25 cycles from 12 animals, we obtained intervals of $\simeq 27 \cdot 3 \mathrm{~h}$ between the beginning of the $\mathrm{LH}$ peak and ovulation and $\simeq 17.5 \mathrm{~h}$ between the end of the peak and ovulation. This modified technique can be used to predict rapidly and precisely the time of ovulation in cattle.
\end{abstract}

\section{Introduction}

Studies on bovine follicular oocytes have shown that maturation in vitro impaired their ability to develop normally but this was not observed with oocytes obtained from heifers slaughtered $24 \mathrm{~h}$ after hCG injection (Trounson, Willadsen \& Rowson, 1977). The time elapsed after LH discharge is important for normal oocyte maturation. Therefore, one of the first prerequisites for successful in-vitro fertilization is to obtain follicular oocytes as close as possible to the time of natural ovulation. Since the preovulatory surge of LH appears to be the most distinctive and reliable event preceding ovulation (Brown, 1977; Pauerstein et al., 1978; Moghissi, 1980) we have devised a rapid and practical plasma $\mathrm{LH}$ radioimmunoassay to provide an accurate approach for predicting the imminence of ovulation in cows.

\section{Materials and Methods}

All assays were carried out in $0.05 \mathrm{M}$-sodium phosphate buffer ( $\mathrm{pH} 7.5$ ) containing $0.1 \%$ bovine serum albumin (BSA; B.D.H. Chemicals, Toronto, Canada) and $0 \cdot 1 \%$ sodium azide. This was the radioimmunoassay (RIA) buffer. The LH preparation for iodination (LER-1374A or 1397; NIH) and the LH reference preparation used as standard (ovine LH-21, NIAMDD-NPA) reacted with a bovine anti-LH serum (anti-B-LH P-2, DSS contract OZSV 01845-6-1002). The antiserum and LH preparations were obtained through the M.R.C. group in the Molecular Endocrinology Laboratory at Laval University. The antiserum was diluted in the radioimmunoassay buffer containing heat- 
treated rabbit blood serum (RHBS; $1 / 250: \mathrm{v} / \mathrm{v}$ ) and $50 \mathrm{~mm}$-ethylenediamine tetraacetic acid disodium salt (EDTA) (B.D.H. Chemicals, Poole, U.K.). The second antibody (rabbit anti- $\gamma$ globulins) raised in goat was diluted in RIA buffer without BSA whereas polyethylene glycol 4000 (PEG $70 \mathrm{~g} / 1$ ) (B.D.H. Chemicals, U.K.) was prepared with the RIA buffer.

LH iodination. Purified LH (LER-1374A or 1397) was iodinated by the chloramine T method as described by Greenwood, Hunter \& Glover (1963) using $2.0 \mu \mathrm{g}$ hormone, $50 \mu 10.5 \mathrm{M}$-sodium phosphate buffer, $8 \cdot 0 \mu \mathrm{l}^{125} \mathrm{I}(400 \mu \mathrm{Ci}$; New England Nuclear, Boston, Massachusetts, U.S.A.), $5 \cdot 0$ $\mu l$ chloramine $\mathrm{T}(5 \mathrm{mg} / \mathrm{ml})$ and, after $1 \mathrm{~min}, 25 \mu 1$ sodium metabisulphite $(2.4 \mathrm{mg} / \mathrm{ml}$; Fischer Scientific, Fair Lawn, New Jersey, U.S.A.) and $250 \mu \mathrm{I}$ potassium iodide $(10 \mathrm{mg} / \mathrm{ml}$; Anachemia Chemical, Toronto, Canada). The last three reagents were dissolved in distilled water. The iodinated hormone was separated from free iodine by chromatography on Sephadex G-50.

Animals. The heifers used were Holsteins 12-30 months of age. In Exp. 1, oèstrus was detected by observing bull-to-heifer or heifer-to-heifer behaviour at 4-h intervals between 07:30 and 16:00 $\mathrm{h}$. The bull had a surgically deflected penis. In Exp. 2, when the animal was expected to become oestrous the same schedule was used overnight. The beginning of oestrus was defined as the moment when, for the first time, the animal stayed still when the bull was mounting. The middle point between two consecutive observations was used when a heifer was not in oestrus at the first observation but was in full oestrus $4 \mathrm{~h}$ later.

Plasma collection. Blood was recovered from the jugular vein. In Exp. 1, blood collection at 4-h intervals began 1 day before the expected time of oestrus and lasted until the day of oestrus inclusively. Blood was collected during daylight hours only $(08: 00,12: 00$ and 16:00 h) for 11 cycles, but for 8 cycles collection was extended until $12 \mathrm{~h}$ after the onset of oestrus. Thereafter, for all 19 cycles blood sampling was continued at 4 -day intervals until the next oestrus. In Exp. 2, blood was collected at 2-or 4-h intervals from at least $48 \mathrm{~h}$ before the expected time of oestrus to $10 \mathrm{~h}$ after the end of the oestrus and thereafter at intervals of 2 or 4 days until the next oestrus. In all cases, blood was kept in EDTA at $4^{\circ} \mathrm{C}$ until centrifugation. The plasma was frozen at $-20^{\circ} \mathrm{C}$ until $\mathrm{LH}$ determination.

Ovulation. Laparoscopy (Rioux, Lambert, D'Amours, Soucy \& Brassard, 1980) was performed on fasting heifers ( $36 \mathrm{~h}$ without food and $12 \mathrm{~h}$ without water) $4 \mathrm{~h}$ before the estimated time of ovulation. In Exp. 1, the state of the follicle (ovulated or not) was recorded at the time of laparoscopy and no further observations were made. In Exp. 2, laparoscopy was performed $4 \mathrm{~h}$ before the estimated time of ovulation but lasted until ovulation $(2-7 \mathrm{~h}$ later $)$. There was no other endoscopy in the same cycle.

Radioimmunoassay. For the rapid assay, $100 \mu \mathrm{l}$ of antibody (bovine anti-LH, 1/50 000) were added to duplicate $100 \mu \mathrm{l}$ samples of standard LH (ovine L H-21, $2 \cdot 5-40 \mathrm{ng} / \mathrm{ml}$ ) plus $100 \mu \mathrm{l}$ buffer or $200 \mu \mathrm{l}$ plasma followed by $100 \mu \mathrm{l}^{125} \mathrm{I}$-labelled LH ( 220000 c.p.m.). After incubation for $2 \mathrm{~h}$ at $37^{\circ} \mathrm{C}$ in a water bath, separation of the immune complex was carried out by addition of $50 \mu \mathrm{l}$ rabbit anti- $\gamma$-globulin $(1 / 6)$ plus $500 \mu \mathrm{l}$ polyethylene glycol $4000(70 \mathrm{~g} / \mathrm{l})$. The tubes were incubated at room temperature for $30 \mathrm{~min}$, and then centrifuged at $1520 \mathrm{~g}$ for $20 \mathrm{~min}$ at $4^{\circ} \mathrm{C}$. The supernatants were gently poured off, the tubes were dried on absorbent paper and counted for $60 \mathrm{sec}$ in a gamma counter (Abbott Laboratories).

The standard assay (long assay) was a modification of the method described by Niswender, Reichert, Midgley \& Nalbandov (1969). All the solutions and reference preparations were the same as in the rapid assay. The antigen-antibody reaction occurred overnight at room temperature and the separation of the immune complex was carried out at room temperature for $2 \mathrm{~h}$. Polyethylene glycol was not added but $1 \mathrm{ml}$ saline $(9 \mathrm{~g} \mathrm{NaCl} / \mathrm{l})$ was added just before the centrifugation. The next steps were similar to those described for the rapid assay. The sensitivity of the long assay was 0.6 $\mathrm{ng} / \mathrm{ml}$. Parallelism was observed between the standard curve and the results with various dilutions of plasma. Variation between the slopes of linearized curves (logit transformation of $y$ axis values) was $5 \%$, where the slope of the standard curve was -2.800 and dilutions of plasma sample 1 was -2.945 . Cross-reactivity with FSH, TSH and GH was $<1 \%$ and there was none with prolactin. 
The recovery was $94 \%$. Cross-reactivity and recovery tests were carried out by the M.R.C. group in the Molecular Endocrinology Laboratory at Laval University.

\section{Results}

The rapid plasma LH radioimmunoassay was used for 12 heifers and 25 oestrous cycles ( 1 cycle, 2 animals; 2 cycles, 7 animals; 3 cycles, 3 animals). Table 1 shows the main characteristics of the assay. The beginning of the LH rise was estimated to be the first significant and irreversible elevation of LH corresponding to an increase of $50 \%$ over the baseline values and the end of the peak was defined as being the return to $25 \%$ over the baseline value (Text-fig. 1). The values obtained are shown in Table 2; maximum levels of plasma LH were variable, with values as low as $6 \mathrm{ng} / \mathrm{ml}$ and higher than $20 \mathrm{ng} / \mathrm{ml}$ (Text-fig. 1; Table 2).

Three characteristics were related to ovulation (Table 2). In each of Exps 1 and 2,6 ovulations (5 animals) were observed laparoscopically: 5 of the 6 ovulations in Exp. 2 were observed in detail and, in all 5, a follicular apical protrusion was seen.

Table 1. Characteristics of the rapid $\mathrm{LH}$ radioimmunoassay

\begin{tabular}{|c|c|}
\hline $\begin{array}{l}\text { Intra-assay variation } \\
\text { Inter-assay coefficient of variation* } \\
\text { Coefficient of variation between rapid and standard radioimmunoassay* } \\
\text { Non-specific binding } \\
\text { Total binding } \\
\text { Sensitivity }(2 \times \text { s.d. of the zero response) } \\
\text { Recovery }(n=5) \\
\text { Linear range } \\
\text { Correlation coefficient }\left(r^{2}\right)\end{array}$ & $\begin{array}{l}<5 \% \\
<12 \% \\
<15 \% \\
3-8 \% \\
20-29 \% \\
0.9 \mathrm{ng} / \mathrm{ml} \\
117 \% \\
2.5-20 \mathrm{ng} / \mathrm{ml} \\
0.98 \\
(y=0.89 x+0.22) \dagger\end{array}$ \\
\hline
\end{tabular}

Table 2. Characteristics of the LH peak in heifers and their relation to oestrus and ovulation

\begin{tabular}{|c|c|c|c|c|}
\hline & & Exp. 1 & Exp. 2 & Exp. $1+$ Exp. 2 \\
\hline $\begin{array}{l}\text { Interval between } \\
\text { beginning of LH } \\
\text { rise and ovulation }(\mathrm{h})\end{array}$ & $\begin{array}{c}\text { Mean } \pm \text { s.d } \\
\text { Range } \\
\mathrm{n}^{*}\end{array}$ & $\begin{array}{l}- \\
18 \cdot 0-26 \cdot 5 \\
5(4)\end{array}$ & $\begin{array}{l}27 \cdot 4 \pm 1 \cdot 7 \\
25 \cdot 0-29 \cdot 25 \\
\quad 6(5)\end{array}$ & $\begin{array}{l}27 \cdot 3 \pm 1 \cdot 6 \\
25 \cdot 0-29 \cdot 25 \\
7(6)\end{array}$ \\
\hline $\begin{array}{l}\text { Interval between } \\
\text { end of LH peak } \\
\text { and ovulation }(h)\end{array}$ & $\begin{array}{l}\text { Mean } \pm \text { s.d. } \\
\text { Range } \\
n^{*}\end{array}$ & $\begin{array}{l}12 \cdot 0-21 \cdot 7 \\
13(6)\end{array}$ & $\begin{array}{l}17 \cdot 9 \pm 1 \cdot 4 \\
16 \cdot 7-20 \cdot 5 \\
6(5)\end{array}$ & $\begin{array}{l}17 \cdot 5 \pm 1 \cdot 5 \\
14 \cdot 0-20 \cdot 5 \\
11(9)\end{array}$ \\
\hline $\begin{array}{l}\text { Interval between } \\
\text { beginning of oestrus } \\
\text { and ovulation }(h)\end{array}$ & $\begin{array}{c}\text { Mean } \pm s . d \\
\text { Range } \\
n^{*}\end{array}$ & $\begin{array}{l}-\overline{20 \cdot 0} \\
4(4)\end{array}$ & $\begin{array}{l}26 \cdot 0 \pm 4 \cdot 0 \\
21 \cdot 25-29 \cdot 0 \\
4(4)\end{array}$ & $\begin{array}{l}26 \cdot 0 \pm 4 \cdot 0 \\
21 \cdot 25-29 \cdot 0 \\
4(4)\end{array}$ \\
\hline $\begin{array}{l}\text { Interval between } \\
\text { beginning of oestrus } \\
\text { and beginning of LH peak (h) }\end{array}$ & $\begin{array}{c}\text { Mean } \pm s . d \\
\text { Range } \\
n^{*}\end{array}$ & $\begin{array}{c}-\overline{0-3} \cdot 5 \\
3(3)\end{array}$ & $\begin{array}{c}0.54 \pm 5 \cdot 9 \\
-8 \cdot 0-+9 \cdot 0 \\
6(4)\end{array}$ & $\begin{array}{c}1.0 \pm 4 \cdot 8 \\
-8 \cdot 0+9 \cdot 0 \\
9(7)\end{array}$ \\
\hline Duration of $\mathbf{L H}$ peak (h) & $\begin{array}{c}\text { Mean } \pm \text { s.d. } \\
\text { Range } \\
n^{*}\end{array}$ & $\begin{array}{c}6 \cdot 0-10 \cdot 0 \\
5(3)\end{array}$ & $\begin{array}{c}9 \cdot 5 \pm 1 \cdot 2 \\
7 \cdot 5-11 \cdot 0 \\
8(5)\end{array}$ & $\begin{array}{c}9 \cdot 5 \pm 1 \cdot 0 \\
7 \cdot 5-11 \cdot 0 \\
11(7)\end{array}$ \\
\hline
\end{tabular}

* No. of cycles (no. of animals). 


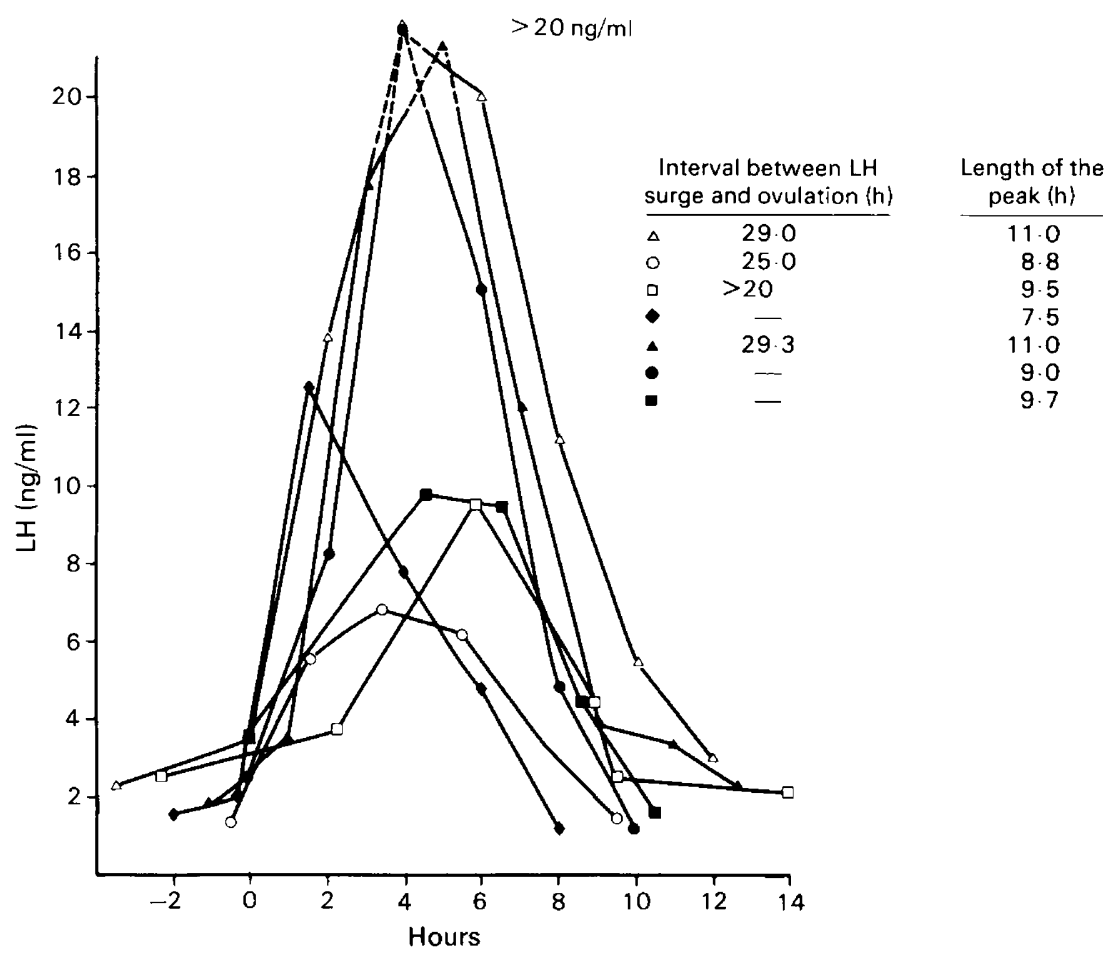

Text-fig. 1. Profiles of LH peaks in the plasma of preovulatory cows. Each symbol represents an individual cycle. The first significant $\mathrm{LH}$ rise, corresponding to an increase of $50 \%$ over the baseline value, is taken as $0 \mathrm{~h}$. The baseline is not illustrated but was estimated from at least 10 plasma samples.

\section{Discussion}

The coefficient of variation between the standard assay and our rapid assay was less than $15 \%$. The assay described here is reliable and its main advantage is its rapidity. However, the percentage of ${ }^{125} \mathrm{I}$ binding $\left(\mathrm{B}_{0} / \mathrm{T}\right)$ is low $(20-29 \%)$ and freshly iodinated $\mathrm{LH}(<7$ days old $)$ is required. Plasma $\mathrm{LH}$ determinations during complete oestrous cycles have shown that, in agreement with the results of Hansel \& Echternkamp (1972), Snook, Saatman \& Hansel (1971), Christenson, Echternkamp \& Laster (1975) and Garverick, Erb, Niswender \& Callahan (1971), the basal level of LH varies generally between 1 and $4 \mathrm{ng} / \mathrm{ml}$, while peak values range from 6 to $>20 \mathrm{ng} / \mathrm{ml}$ (Schams \& Karg, 1969; Christenson et al., 1975). The mid-cycle LH peak described by Snook et al. (1971) was not observed in our study, probably because of the 2-4-day interval between two consecutive blood collections.

Using direct morphological observations of the ovaries around the time of ovulation and plasma LH determinations in spontaneous oestrous cycles in cows, we have found that the interval between the beginning of the plasma $\mathrm{LH}$ peak and ovulation is quite regular, ranging from 25 to $29 \mathrm{~h}$ (Table 2). Similar findings were reported for the ewe by Cumming et al. (1973) who used very similar methods (solid-phase radioimmunoassay and laparotomy), but the intervals reported for women (Ben-Aderet et al., 1977; Frydman et al., 1981; De Crespigny, O'Herlihy \& Robinson, 1981; Wetzels \& Hoogland, 1982) are very variable.

The mean interval obtained between the beginning of the LH surge and ovulation $(27 \cdot 3 \pm$ $1.6 \mathrm{~h}$ ) agrees with those reported by Henricks \& Dickey (1970) and Chenault, Thatcher, Kalra, Abrams \& Wilcox (1975) but is smaller than those reported by Schams, Schallenberger, Hoffmann 
\& Karg (1977), Christenson et al. (1975) and Swanson \& Hafs (1971). This discrepancy may be explained by the fact that these authors used rectal palpation at long intervals $(4-6 \mathrm{~h})$ for determination of the moment of ovulation.

We also tried to establish a time relationship between the beginning of oestrus and ovulation. However, intervals between these two events varied widely and therefore the onset of oestrus cannot be used to predict accurately the imminence of ovulation. For example, in 2 heifers, the first significant plasma LH rise appeared before the beginning of oestrus $(-8$ and $-3 \mathrm{~h}$ ) while in all the other animals the LH peak followed the start of oestrus $(0-9 \mathrm{~h})$. These observations reflect those of Hansel \& Echternkamp (1972), Schams et al. (1977), Chenault et al. (1975) and Fietta, Olson \& Gass (1968) who have shown that the LH peak can follow oestrus and those of Swanson \& Hafs (1971) and Christenson et al. (1975) who observed oestrus after the LH peak. The interval between the beginning of oestrus and ovulation is long in the cow, ranging from 16 to $36 \mathrm{~h}$ (Gerasimova, 1940 ) or 16 to $42 \mathrm{~h}$ (Swanson \& Hafs, 1971). The relative proximity of the LH peak and oestrus suggests that detection of the LH peak would be facilitated by close observation of behaviour and collection of blood samples as soon as pro-oestrus is detected.

The end of the LH peak is as precise a criterion as the beginning of the peak but, for practical reasons, the latter is probably the best reference point. Indeed, the LH peak can begin before oestrus and such an $\mathrm{LH}$ rise would be missed by using the former for the reference point. However, there is no reason why the end of the peak should go undetected. This explains why fewer data were obtained in this study for the intervals starting at the beginning of the peak when compared to the intervals starting at the end of the same peak.

In the present study, laparoscopy was used for ovary examination rather than rectal palpation. Observations of the ripe follicles indicated that the morphology of the follicle and apex formation vary considerably between animals. If it occurs, the apex becomes visible about $1 \mathrm{~h}$ before ovulation, and this event is probably the closest indicator of ovulation. However, it is not known whether the formation of an apex always precedes ovulation in cattle. If it does, this would be the best time to puncture follicles to obtain fully mature oocytes.

This simple rapid and reliable LH assay should be of great help for investigators interested in the accurate prediction of ovulation and particularly for those planning to use aspiration of mature follicles for in-vitro fertilization studies.

We thank "le Département de Photographie médicale du C.H.U.L.", particularly Mr Daniel Morand, for photographs and the M.R.C. group in the Molecular Endocrinology Laboratory at the C.H.U.L. for supplying antibovine LH, LH standard, LH for iodination and partial characterization of the long assay. This work was supported by a grant from C.R.S.A.Q. and contracts with Agriculture Canada and P.E.I.T. We thank Dr Louis Nicole for revising the text of the manuscript. C.B. was supported by a studentship from the Georges Phenix Foundation.

\section{References}

Ben-Aderet, N., Potashnik, G., Lunenfeld, B., Kraiem, Z., Grunstein, S. \& Shalit, A. (1977) Correlation of hormonal profile and ovarian morphologic features during the periovulatory period in humans. Fert. Steril. 28, 361-362.

Brown, J.B. (1977) Timing of ovulation. Med. J. Aust. 2, $780-783$.

Chenault, J.R., Thatcher, W.W., Kalra, P.S., Abrams, R.M. \& Wilcox, C.J. (1975) Transitory changes in plasma progestins, estradiol and luteinizing hormone approaching ovulation in the bovine. J. Dairy $S c i .58$, 709-717.

Christenson, R.K., Echternkanp, S.E. \& Laster, D.B.
(1975) Oestrus, LH, ovulation and fertility in beef heifers. J. Reprod. Fert. 43, 543-546.

Cumming, I.A., Buckmaster, J.M., Blockey, M.A. de B., Goding, J.R., Winfield, C.G. \& Baxter, R.W. (1973) Constancy of interval between luteinizing hormone release and ovulation in the ewe. Biol. Reprod. 9, 24 29.

De Crespigny, L.C., O'Herlihy, C. \& Robinson, H.P. (1981) Ultrasonic observation of the mechanism of human ovulation. Am. J. Obstet. Gynec. 139, 636-639.

Fietta, P.M., Olson, H.H. \& Gass, G.H. (1968) Luteinizing hormone in cow plasma during estrus. $J$. Dairy Sci. 51, 949. 
Frydman, F., Feinstein, M.C., Testart, J., Thebault, A., Labbé, A., Grenier, J., Roger, M. \& Scholler, R. (1981) Recueil d'ovocytes humains en phase préovulatoire. Intérêt du dosage radioimmunologique rapide de la LH plasmatique. J. Gynaec, Obstet., Biol. Reprod. 10, 127-132.

Garverick, H.A., Erb, R.E., Niswender, G.D. \& Callahan, C.J. (1971) Reproductive steroids in the bovine. III. Changes during the estrous cycle. J. Anim. Sci. 32, 946-956.

Gerasimova, A.A. (1940) Duration of heat and time of ovulation in the cow. Anim. Breed. Abstr. 8, 32.

Greenwood, F.C., Hunter, W.M. \& Glover, J.S. (1963) The preparation of ${ }^{131} \mathrm{I}$ labelled human growth hormone of high specific radioactivity. Biochem. $J$. 89, $114-123$.

Hansel, W. \& Echternkamp, E. (1972) Control of ovarian function in domestic animals. Am. Zool. 12, 225-243.

Henricks, D.M. \& Dickey, J.F. (1970) Serum luteinizing hormone and plasma progesterone levels during the estrous cycle and early pregnancy in cows. Biol. Reprod. 2, 346-351.

Moghissi, K.S. (1980) Prediction and detection of ovulation. Fert. Steril. 34, 89-98.

Niswender, G.D., Reichert, L.E., Jr, Midgley, A.R. \& Nalbandov, A.V. (1969) Radioimmunoassay for bovine and ovine luteinizing hormone. Endocrinology 84, 1166-1173.

Pauerstein, C.J., Eddy, C.A., Croxatto, H.D., Hess, R., Siler-Knods, T.M. \& Croxatto, H.B. (1978) Temporal relationship of estrogen, progesterone and luteinizing hormone levels to ovulation in woman and infrahuman primates. Am. J. Obstet. Gynec. 130, 876886.

Rioux, J.E., Lambert, R.D., D'Amours, D., Soucy, B. \& Brassard, A. (1980) Prélèvement des ovules de bovins par laparoscopie: résultats préliminaires. Un. Med. Can. 109, 535-547.

Schams, D. \& Karg, H. (1969) Radioimmunologische LH-bestimmung im Blutserum vom Rind unter besonderer Berucksichtigung des Brunstzyklus. Acta endocr., Copenh. 61, 96-103.

Schams, D., Schallenberger, E., Hoffmann, B. \& Karg, H. (1977) The oestrous cycle of the cow: hormonal parameters and time relationships concerning oestrus, ovulation and electrical resistance of the vaginal mucus. Acta endocr., Copenh. 86, 180-192.

Snook, R.B., Saatman, R.R. \& Hansel, W. (1971) Serum progesterone and luteinizing hormone levels during the bovine estrous cycle. Endocrinology 88, 678-686.

Swanson, L.V. \& Hafs, H.D. (1971) LH and prolactin in blood serum from estrus to ovulation in Holstein heifers. J. Anim. Sci. 33, 1038-1041.

Trounson, A.O., Willadsen, S.M. \& Rowson, L.E.A. (1977) Fertilization and developmental capability of bovine follicular oocytes matured in vitro and in vivo and transferred to the oviducts of rabbits and cows. $J$. Reprod. Fert. 51, 321-327.

Wetzels, L.C.G. \& Hoogland, H.J. (1982) Relation between ultrasonographic evidence of ovulation and hormonal parameters: luteinizing hormone surge and initial progesterone use. Fert. Steril. 37, 336-341.

Received 30 November 1982 